\title{
The response of tomato (Lycopersicon esculentum Mill.) transplants to mechanical stress
}

\author{
PIOTR M. PISZCZEK and MAREK JERZY
}

Department of Horticulture, Academy of Technology and Agriculture, Bernardyńska 6, 85-029 Bydgoszcz, Poland

(Received: March 11, 1985)

\begin{abstract}
Inhibition of the growth of young tomato plants took place under the influence of vibrational stress. The response of the plants was stronger in winter than in summer. The results of the mechanical stress treatment depended on the dosage: small doses of stress given repeatedly slowed down the growth of the transplant much more effectively than larger single doses given every day or every several days. The fresh weight of the shoots decreased under the influence of the stress, as did the dry weight, but to a smaller degree, thus the percentage of dry weight increased. The chlorophyll content in the leaves of plants treated with mechanical stress also increased.
\end{abstract}

\section{INTRODUCTION}

Supplementary illumination of tomato transplants used for accelerated production under glass or plastic tunnel, effectively prevents their etiolation during the fall-winter insolation deficit. It also allows earlier, higher and better quality yields to be obtained. This is, however, a very energy-consuming method which, in addition, is becoming increasingly more expensive. For this reason, studies have been in progress for many years on substituting supplementary illumination by chemical agents inhibiting excessive growth of the transplant (M i c h n i ew ic z, 1966).

Numerous studies have shown that although synthetic growth-retarding substances reverse the negative effects of light deficiency and prevent the etiolation of transplants (Will, 1966; Wojtaszek et al., 1977; Pisarczyk and Splittstoesser, 1979), they very often lower the fruit yield ( $\mathrm{J}$ a s a et al., 1973) and usually exert an unfavorable influence on their chemical composition - especially on the dry weight and Vit. C contents (Dobrowolski et al., 1969; I brahim et al., 
1979). It is also hard to exclude a harmful or even toxic effect of chemical retardants on the human organism.

It is known that mechanical stimuli evoking stress in plants can be as effective as chemicals in preventing excessive growth, while not causing any damage or other negative side-effects ( $\mathrm{M}$ i $\mathrm{t} \mathrm{ch}$ e 11 et al., 1975; Klapwijk and Wubben, 1975; Jerzy and Nowaczyk, 1977). It has been shown that inhibition of plant growth is accompanied by a decrease in the internode length while the total number of leaves remains unchanged. It has also been found that the reaction of the plant to stress is dependent on the strength of the mechanical stimulus and age of the plant ( $\mathrm{Mitch}$ e 11,1977; J er zy et al, 1981).

However, many theoretical and practical questions which could have a bearing on the introduction of this phenomenon into horticultural practice, have not to date been addressed.

The objective of the experiments presented in this paper was to obtain more information on the reaction of the greenhouse tomato (Lycopersicon esculentum Mill.) to mechanical stress evoked by vibration of the plant. The influence of stress on the growth of the plant was studied by applying different doses of mechanical stimuli (Experiment A) and its different duration (Experiment B). The reaction of the transplants was also compared in cultures run in the summer and winter (Experiment A).

\section{MATERIAL AND METHODS}

Tomato transplants (Lycopersicon esculentum Mill.) of 'Nortona $\mathrm{T}_{\mathrm{m}} \mathrm{C}_{4}$ ' cultivar growing in pots were subjected to vibration daily, 6 days per week excluding Sundays, on a type WS-2 shaker, starting from the time the second leaf was formed until the first flower buds appeared on the shoot tip. Each Sunday, the plants were measured in order to determine their growth dynamics. At the conclusion of the experiment, the percentage of growth reduction was calculated and the following measurements and assays done: number of leaves, length of internodes, stem thickness, fresh and dry weight of stems (dryer method) and chlorophyll content in leaves on the basis of a standard solution ( $\mathrm{C} \mathrm{z}$ os now ski, 1976).

The results were analysed statistically by the variance analysis method with a single classification.

\section{Experiment A}

The experiment was carried out in the winter of 1981 and repeated in the following summer.

The seeds were sown on January 5 and June 10, respectively. The seedlings were transplanted into pots $10 \mathrm{~cm}$ in diameter: after 29 days 
in the winter and 20 days in the summer. They were grown on well-decomposed pine bark compost with cow-dung and peat added.

On March 1 and July 12, when the transplants had developed a second leaf, 280 plants of equal height and otherwise well-equalized, were selected from a total of 500 plants prepared on each date. The selected plants were then divided into 7 groups, 40 plants in each. One of them was the control group (C), the 6 remaining groups were subjected to vibration in the following way:

I - six times per day, for $5 \mathrm{~s}^{*}$, at $8.00,10.00,12.00,14.00,16.00$ and 18.00 hours;

II - three times per day, for $10 \mathrm{~s}$, at $8.00,10.00$ and 12.00 hours;

III - two times per day, for $15 \mathrm{~s}$, at 8.00 and 10.00 hours;

IV - once per day, for $30 \mathrm{~s}$, at 8.00 hours;

$\mathrm{V}$ - every other day, for $60 \mathrm{~s}$, on Mondays, Wednesdays, Fridays at 8.00 hours;

VI - every third day, for $90 \mathrm{~s}$ on Mondays and Thursdays at 8.00 hours.

In all of the groups, the plants received during the six days of the week the same, 180 second total dose of vibration, only the dosage of the stress stimulus differed.

During the winter, the transplants were grown under natural lighting conditions, without supplementary light. During this period, the air temperature of the greenhouse was $14-18^{\circ} \mathrm{C}$ during the day and $10-12^{\circ} \mathrm{C}$ at night. During the summer the temperature was $30-35^{\circ} \mathrm{C}$ during the day and $23-25^{\circ} \mathrm{C}$ at night.

\section{Experiment B}

In Experiment $A$, the total weelkly amount of the stress factor regardless of the way it was dosed, was always $180 \mathrm{~s}$. In Experiment B, however, the dose was lower $(0.5-1.5 \mathrm{~min})$, the same $(3 \mathrm{~min})$ or higher (6-108 $\mathrm{min})$. Studied here were the reactions of transplants to the stress factor applied once daily at 8.00 for $5,15,30,60,90$ and $180 \mathrm{~s}$, or repeatedly six times for $5,15,30,60,90$ and $180 \mathrm{~s}$, in two-hour intervals from 8.00-18.00 hours.

This way of structuring the experiment was intended to help answer the question if the stress factor applied in Experiment A was strong enough to evoke the maximum physiological effect, symptomized by inhibition of the growth processes, without causing any damage to the above-ground plant parts.

The seeds were sown on September 7, 1982. After 22 days, the seedlings were transplanted to pots $10 \mathrm{~cm}$ in diameter. On October 17 , when

* The shaker made 8 horizontal reciprocal motions during 5 s. 

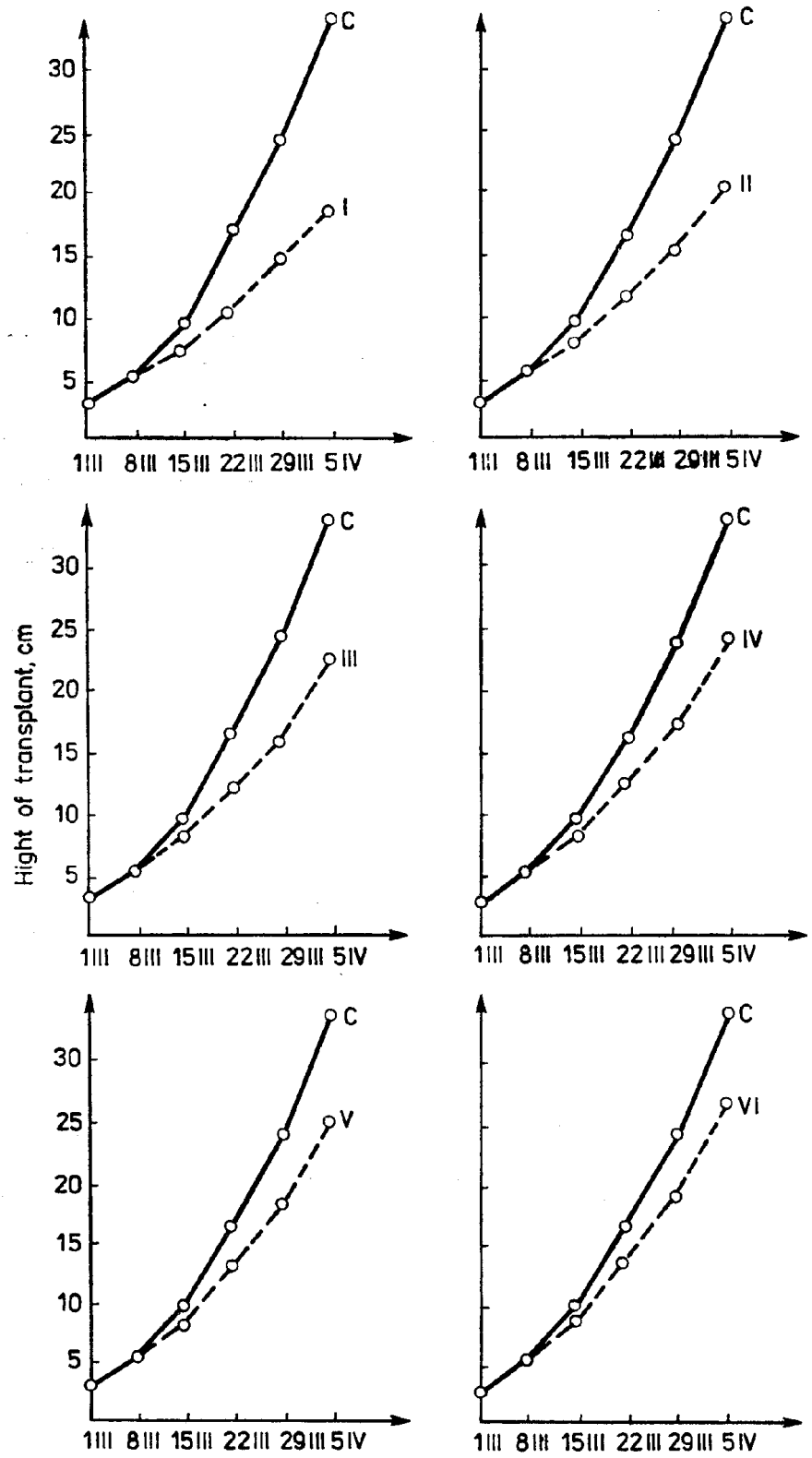

Fig. 1. The dynamics of growth of a tomato transplant treated with mechanical stress during greenhouse cultivation in winter: I - six times per day, for $5 \mathrm{~s}$ at $8.00,10.00,12.00,14.00,16.00$ and 18.00 hours; II - three times per day, for $10 \mathrm{~s}$ at $8.00,10.00$ and 12.00 hours; III - twice per day, for $15 \mathrm{~s}$ at 8.00 and 10.00 hours; IV - once per day, for $30 \mathrm{~s}$ at 8.00 hours; V - every second day, for $60 \mathrm{~s}$ on Mondays, Wednesdays and Fridays at 8.00 hours; VI - every third day, for $90 \mathrm{~s}$ on Mondays and Thursdays at 8.00 hours; $\mathrm{C}-$ control 
the plants had formed a second leaf, 280 of the most equalized, with an average height of $7.4 \mathrm{~cm}$, were chosen for study. They were divided into 14 groups with 20 plants per group: two groups were controls, 6 groups were given stress once per day and 6 groups -6 times per day.

The application of vibration once per day for 5-180 s was stopped on November 20, after 5 weeks, when flower buds appeared on the plants. The remaining groups of plants subjected to vibration 6 times per day were removed from the experiment two weeks earlier - on November 6 . This was necessary because many of the plants had begun to bend and break during growth.

Biometrical measurements and fresh and dry weight determinations were done on November 7 and 21, respectively.

The air temperature of the greenhouse during the growth of the transplants was $17-19^{\circ} \mathrm{C}$ during the day and $12-13^{\circ} \mathrm{C}$ at night.

\section{RESULTS}

Subjecting tomato transplants to mechanical stress caused by vibration of the entire plants, caused significant inhibition of their growth. It was also found that the reaction of the plants was greater in the winter than in the summer (Figs. 1 and 2).

The effectiveness of the stress factor depended on the manner in which it was applied: small doses of stress applied frequently during the day were more effective in inhibiting growth than larger single doses applied daily or every few days (Table 1).
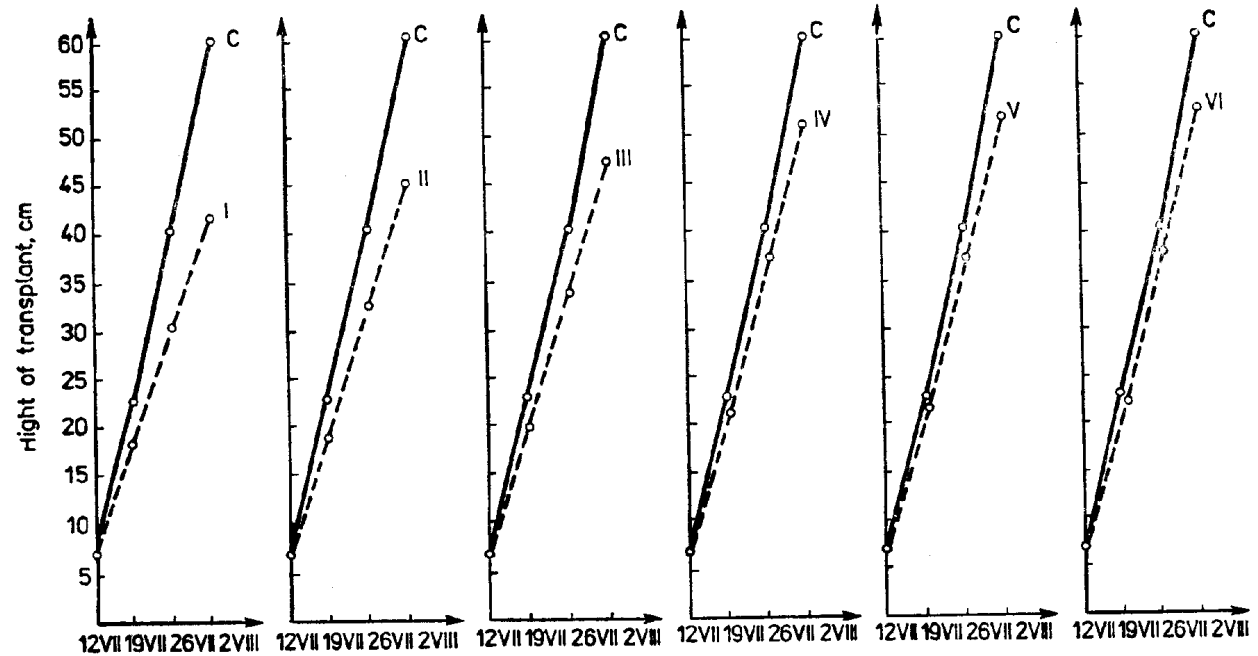

Fig. 2. The dynamics of growth of a tomato transplant treated with mechanical stress during greenhouse cultivation in summer. Explanations - see Fig. 1 


\section{Ta ble 1}

The characteristics of a tomato transplant treated with mechanical stress during winter and summer, depending of the dosage*

\begin{tabular}{|c|c|c|c|c|c|c|c|c|c|}
\hline $\begin{array}{l}\text { Way of } \\
\text { stress dosage }\end{array}$ & $\begin{array}{l}\text { Height of } \\
\text { shoots } \\
\text { cm }\end{array}$ & $\begin{array}{c}\text { Reduction } \\
\text { of height } \\
\%\end{array}$ & $\begin{array}{c}\text { Number } \\
\text { of } \\
\text { leaves }\end{array}$ & $\begin{array}{l}\text { Length of } \\
\text { internode } \\
\quad \mathrm{mm}\end{array}$ & $\begin{array}{c}\text { Thickness } \\
\text { of stem } \\
\mathrm{mm}\end{array}$ & $\begin{array}{c}\text { Fresh weight } \\
\text { of shoots } \\
\mathrm{g}\end{array}$ & $\begin{array}{l}\text { Dry weight } \\
\text { of shoots } \\
\mathrm{g}\end{array}$ & $\begin{array}{c}\text { Contents } \\
\text { of dry weight } \\
\%\end{array}$ & $\begin{array}{c}\text { Contents of } \\
\text { chlorophyll } \\
\text { in leaves } \\
\mathrm{mg} / \mathrm{g}\end{array}$ \\
\hline \multicolumn{10}{|l|}{ Winter } \\
\hline Control & 34.0 & - & 10.2 & 33.3 & 6.8 & 28.82 & 2.31 & 8.00 & 3.07 \\
\hline I & 18.7 & 45.0 & 9.7 & 19.3 & 6.8 & 23.34 & 2.04 & 8.76 & 3.28 \\
\hline II & 20.6 & 39.4 & 9.7 & 21.2 & 6.6 & 25.32 & 2.07 & 8.16 & 3.25 \\
\hline III & 22.8 & 32.9 & 9.8 & 23.3 & 6.6 & 25.84 & 2.02 & 7.80 & 3.28 \\
\hline IV & 24.6 & 27.6 & 9.9 & 24.8 & 6.5 & 25.72 & 2.04 & 7.92 & 3.27 \\
\hline V & 25.7 & 24.4 & 9.9 & 26.0 & 6.5 & 27.14 & 2.23 & 8.20 & 3.28 \\
\hline VI & 26.9 & 20.9 & 9.9 & 27.2 & 6.6 & 26.96 & 2.22 & 8.23 & 3.20 \\
\hline LSD $<5 \%>$ & 1.8 & - & 0.5 & 1.7 & 0.3 & 1.60 & 0.15 & 0.44 & 0.17 \\
\hline \multicolumn{10}{|l|}{ Summer } \\
\hline Control & 60.6 & - & 11.0 & 55.1 & 8.1 & 41.25 & 3.33 & 8.08 & 3.51 \\
\hline I & 41.9 & 30.8 & 10.5 & 40.0 & 8.1 & 35.57 & 3.14 & 8.84 & 3.70 \\
\hline II & 45.3 & 25.2 & 10.4 & 43.6 & 7.9 & 36.25 & 2.96 & 8.16 & 3.65 \\
\hline III & 47.7 & 21.3 & 10.4 & 45.9 & 8.0 & 36.07 & 2.85 & 7.89 & 3.70 \\
\hline IV & 51.2 & 15.5 & 10.3 & 49.7 & 8.0 & 37.12 & 2.94 & 7.92 & 3.65 \\
\hline $\mathrm{V}$ & 52.3 & 13.7 & 10.3 & 50.8 & 8.1 & 38.21 & 3.07 & 8.04 & 3.60 \\
\hline VI & 53.0 & 12.5 & 10.4 & 51.0 & 8.1 & 38.53 & 3.14 & 8.14 & 3.69 \\
\hline LSD $<5 \%>$ & 2.3 & - & 0.6 & 2.0 & 0.3 & 1.95 & 0.19 & 0.39 & 0.17 \\
\hline
\end{tabular}

* I-VI For explanations see Figure 1. 
The more frequently the plant was subjected to stress, the more the growth was inhibited, in spite of the fact that the total weekly dose was the same. The greatest reduction in height was observed in plants subjected to stress 6 times per day at 2 hour intervals; during the winter it equaled $45 \%$, during the summer $-30.8 \%$. Stress applied less frequently but in higher single doses was less effective in inhibiting the growth of the transplant. The plants subjected to stress every three days showed the lowest reduction in height although the amount of stress applied was in this case increased by a factor of 3 . It was also found that during the winter the height of the transplants was lower by $20.9 \%$, in the summer by $12.5 \%$.

The reaction of the plants to the time the stress factor was applied (varied from 5 to $180 \mathrm{~s}$ ) depended on if the plants were vibrated once or many times per day (Table 2).

When the stress factor was applied once daily, the inhibition of growth was greater the longer the factor had been applied; the maximal effect was observed when the plant was stressed for $90 \mathrm{~s}$ continuously. The prolongation of vibration to $180 \mathrm{~s}$ daily did not significantly increase the effect caused by $90 \mathrm{~s}$ application of the stress factor. When the plants were treated with the stress factor repeatedly daily, the maximal inhibition of growth was already attained when this stimulus was applied for a total of only $30 \mathrm{~s}$ - applied in six 5-second doses. This means that the reduction in height observed in plants treated with the stress factor 6 times per day was not dependent on the length of its single application. In both cases, the stress did not cause any damage to the above-ground plant parts.

The stress did not exert a significant influence on either the stem thickness or number of leaves formed by the transplant, while the internode length decreased in the treated plants.

The fresh weight of the shoots decreased under the influence of stress; the dry weight also increased, but to a lower extent - thus the percentage of dry weight in some of the plants subjected to stress, increased. A significant increase in the percentage of dry weight was found only in those plants whose growth had been maximally inhibited as the result of vibration 6 times per day.

These plants were also characterized by a significantly higher chlorophyll content in their leaves.

\section{DISCUSSION}

The experiments performed in this study mainly dealt with the external, observable effects of mechanical stress on a plant. In respect to the most important symptoms, they turned out to be strikingly similar 
Table 2

The characteristics of a tomato transplant treated with mechanical stress once and six times per day for 5-180 $\mathrm{s}$

\begin{tabular}{|c|c|c|c|c|c|c|c|c|c|}
\hline & $\begin{array}{c}\text { Duration } \\
\text { of stress } \\
\text { treatment }\end{array}$ & $\begin{array}{l}\text { Height } \\
\text { of shoots } \\
\mathrm{cm}\end{array}$ & $\begin{array}{c}\text { Reduction } \\
\text { of height } \\
\%\end{array}$ & $\begin{array}{l}\text { Number } \\
\text { of leaves }\end{array}$ & $\begin{array}{c}\text { Length } \\
\text { of internode } \\
\mathrm{mm}\end{array}$ & $\begin{array}{c}\text { Thickness } \\
\text { of stem } \\
\text { mm }\end{array}$ & $\begin{array}{c}\text { Fresh weight } \\
\text { of shoots } \\
\mathrm{g}\end{array}$ & $\begin{array}{c}\text { Dry weight } \\
\text { of shoots } \\
g\end{array}$ & $\begin{array}{c}\text { Contents } \\
\text { of dry weight } \\
\%\end{array}$ \\
\hline \multicolumn{2}{|r|}{ Control } & 39.4 & - & 10.4 & 37.9 & 6.7 & 31.25 & 2.33 & 7.46 \\
\hline \multirow{7}{*}{ 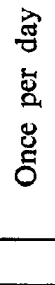 } & $5 \mathrm{~s}$ & 37.1 & 5.8 & 10.3 & 36.0 & 6.6 & 30.94 & 2.21 & 7.14 \\
\hline & $15 \mathrm{~s}$ & 35.5 & 9.9 & 10.3 & 34.5 & 6.6 & 29.68 & 2.21 & 7.44 \\
\hline & $30 \mathrm{~s}$ & 34.6 & 12.2 & 9.9 & 34.9 & 6.6 & 29.76 & 2.21 & 7.44 \\
\hline & $60 \mathrm{~s}$ & 33.4 & 15.2 & 10.0 & 33.4 & 6.7 & 29.65 & 2.17 & 7.32 \\
\hline & $90 \mathrm{~s}$ & 31.5 & 20.1 & 10.1 & 31.2 & 6.8 & 28.12 & 2.13 & 7.58 \\
\hline & $180 \mathrm{~s}$ & 31.8 & 19.3 & 10.1 & 31.5 & 6.7 & 28.46 & 2.14 & 7.52 \\
\hline & LSD $<5 \%>$ & 2.0 & - & 0.5 & 1.6 & 0.2 & 1.47 & 0.12 & 0.46 \\
\hline \multirow{2}{*}{ 丞 } & Control & 23.6 & - & 8.1 & 29.1 & 6.3 & 14.72 & 1.13 & 7.68 \\
\hline & $5 \mathrm{~s}$ & 16.8 & 28.8 & 7.8 & 21.5 & 6.3 & 10.58 & 0.85 & 8.04 \\
\hline \multirow{3}{*}{$\begin{array}{l}\text { 岁 } \\
\text { 岁 } \\
. \Xi\end{array}$} & $15 \mathrm{~s}$ & 16.9 & 28.4 & 7.7 & 21.9 & 6.3 & 11.05 & 0.87 & 7.90 \\
\hline & $30 \mathrm{~s}$ & 16.8 & 28.8 & 7.8 & 21.5 & 6.2 & 10.65 & 0.84 & 7.86 \\
\hline & $60 \mathrm{~s}$ & 16.7 & 29.2 & 7.8 & 21.4 & 6.3 & 10.72 & 0.85 & 7.94 \\
\hline \multirow{3}{*}{$\stackrel{x}{a}$} & $90 \mathrm{~s}$ & 16.3 & 30.9 & 7.7 & 21.2 & 6.3 & 10.94 & 0.86 & 7.87 \\
\hline & $180 \mathrm{~s}$ & 16.3 & 30.9 & 7.8 & 21.2 & 6.2 & 11.01 & 0.86 & 7.81 \\
\hline & LSD $<5 \%>$ & 1.5 & - & 0.4 & 1.3 & 0.2 & 1.12 & 0.06 & 0.42 \\
\hline
\end{tabular}


to the effects obtained by using chemical growth regulators of a retardant nature.

The transplants became dwarfed as the result of the decrease in internode length, the intensity of the green color of the leaves increased. No deformations in the shape of the plants took place.

The results obtained in this study support the hope that this method may find use in horticultural practice and replace the retardants now used in transplant production. They do not, however, give a basis for drawing wider, theoretical generalizations, especially on the mechanisms of dwarfing of plants in effect of mechanical stimuli. In the same way, the results obtained by authors cited in this paper, still are too insubstantial to form a firm basis for explaining the mechanism of stress. For this reason, it seems necessary and purposeful to undertake further, more detailed studies.

The reports by $\mathrm{R}$ e es and Grace $(1980 a, b ; 1981)$ allow the association of the essence of the stress evoked by the mechamical effect of wind or shaking of plants with water stress. These suggestions, however, result from experiments conducted on a woody plant (Pinus contorta) and it is difficult to transfer them directly to an annual plant such as the tomato.

\section{REFERENCES}

Czosnowski J., 1976. Przewodnik do ćwiczeń z fizjologii roślin. Skrypt UAM, Poznań p. 111-112.

Dobrowolski J., Ś c ią $\dot{z}$ o D., W e s o 1 ow ska T., 1969. Wpływ chlorku chlorocholiny na oksydoreduktazy pomidorów, skorzonery i cykorii. Roczn. Nauk Roln. A 95, 1: 97 .

Ibrah im M.A., Abdel-Hamid M.F., El-S a ied M.Z., 1979. Tomato growth, yield and chemical composition of plant and fruits as affected by different CCC and B-9 rates. Zagazig Journal of Agri. Res. 3: 349-361.

Jasa B., Sacharova E., Majernikova V., 1973. Morforegulácni pripravky $\mathrm{v}$ zelinŕstvi. Zahr. Listy 6.

Jerzy M., Nowaczyk P., 1977. Retardacja mechaniczna pomidorów uprawianych w szklarni. Ogrodnictwo 11: 292-294.

Jerzy M., Nowaczyk P., Piszczek P., 1981. Wzrost, kwitnienie i plonowanie pomidorów szklarniowych poddanych działaniu stresu mechanicznego. Zesz. Nauk. ATR w Bydgoszczy, Rolnictwo 13: 145-154.

Klapwijk D., Wubben C. F. M., 1975. The effect of shaking of the shoot tips on the growth of tomato plants. Glasshouse Crops Research and Experiment Station, Naaldwijk, Annual Raport.

Michnie wicz M., 1966. Krytyczna ocena dotychczasowego stanu badań i perspektywy praktycznego stosowania substancji wzrostowych. Post. Nauk Roln. 4: 77-97.

Mitchel1 C. A., Severson C. J., Wott J. A., Hammer P. A., 1975. Seismomorphogenic regulation of plant growth. J. Amer. Soc. Hort. Sci, 100: 161-165.

Mitchell C. A., 1977. NASA launches a new experiment to explore how plants react to stress. Horticulture 9: 10-13. 
Pis a rczyk J. M., Splitts toesser W. E., 1979. Controlling tomato transplant height with chlormequat, daminozide and etephon. J. Amer. Soc. Hort. Sci. 104: $342-344$.

Rees D. J., Grace J., 1980a. The effects of wind on the extension growth of Pinus contorta Douglas. Forestry 53: 146-153.

Rees D. J., Grace J., 1980b. The effects of shaking on extension growth of Pinus contorta Douglas. Forestry 53: 155-156.

Rees D. J., Grace J., 1981. The effect of wind and shaking on the water relations of Pinus contorta. Physiol. Plant. 51: 222-228.

W i 11 H., 1966. Erste Versuchsergebnisse mit CYCOCEL in Tomaten. Gartenbauwiss. 1: 115-123.

Wojtaszek T., Libik A., B a ch A., 1977. Wpływ chlorku chlorocholiny i Durasetu na wzrost i plonowanie pomidorów gruntowych. Zesz. Nauk. Akad. Roln. Kraków, Ogrodnictwo 5: 29-46.

\section{Reakcja rozsady pomidora (Lycopersican esculentum Mill.) na stres mechaniczny}

Streszczenie

Pod wplywem stresu mechanicznego wywołanego wibracją następowało istotne zahamowanie wzrostu rozsady pomidora odmiany 'Nortona $\mathrm{T}_{\mathrm{m}} \mathrm{C}_{4}$ ' uprawianej pod szkłem. Zimą reakcja roślin na stres była silniejsza niż latem.

Efektywność działania bodźca stresowego uzależniona była od sposobu jego dozowania: male dawki stresu stosowane wielokrotnie w ciągu dnia oddziaływały bardziej skutecznie na hamowanie wzrostu rozsady niż większe dawki jednorazowe stosowane codziennie lub co kilka dni.

Pod wplywem stresu malała świeża masa pędów; sucha masa równiè̇, ale w mniejszym stopniu - dzięki czemu procentowa zawartość suchej masy uległa zwiększeniu. Zwiększyła się także zawartość chlorofilu w liściach roślin traktowanych stresem. 